\title{
Deciphering the Reservoir Rocks Lithology by Mineralogical Investigations Techniques for an Oilfield in South-West Romania
}

\author{
Gheorghe Branoiu ${ }^{1, *}$, Lazar Avram ${ }^{1}$, Iuliana Ghetiu ${ }^{1}$, Silvian Suditu ${ }^{1}$, and Stefan Pelin ${ }^{1}$ \\ ${ }^{1}$ Oil-Gas University of Ploiesti, Oil-Gas Engineering Faculty, 39 Bucharest Street, 100680, Ploiesti, \\ Romania
}

\begin{abstract}
An important element of the geological modeling of oil reservoirs is represented by determining of the mineralogical composition and rock types as part of the reservoir characterization process. In the paper we provide a comprehensive mineralogo-petrographic study based on petrographic observations and X-rays diffraction investigations made on several Miocene rock samples collected in the wells spudded in an oil field belonging to the Getic Basin. Getic Basin is a prolific petroleum province in Romania and belongs to petroleum systems of the Carpathian Foredeep. The oil exploration in the Getic Basin started more than 100 years ago and resulted in thousands of wells drilled and tens of fields discovered. The oil field is located in the Gorj County, geologically belongs to the internal zone of the Getic Basin, and is a faulted anticline with hydrocarbon accumulations in Burdigalian and Sarmatian deposits. The petrographic study led to the interpreting of the rock samples analyzed as epiclastic sedimentary rocks represented by conglomerates, breccias, sands, sandstones, claystones and marlstones, and carbonate rocks (limestones). $\mathrm{X}$-rays diffraction investigations indicated the phyllosilicates (smectite and illite) as main minerals in the Sarmatian samples, while in the Burdigalian samples were found as main minerals: quartz, feldspars and carbonate minerals. The paper provides detailed information (like petrographic types, composition and microtexture) on the Miocene reservoir rocks belonging to the Getic Basin. Also the data obtained may be used as basis for future reservoir modeling studies in the region.
\end{abstract}

\section{Introduction}

Geological modeling of hydrocarbon reservoirs consists of several processes of which it stands out the geological characterization of the reservoirs. The geological characterization process of hydrocarbon reservoirs is a process in which an interdisciplinary scientific model is created that integrates and reconciles different types of geological and hydrodynamic information from the pore scale where petroleum is reservoired to the sedimentary basin scale. As important components of the geological characterization process we mention identification of rock types and establishing of their mineralogical composition. The paper

* Corresponding author: gbranoiu@yahoo.com 
provide a detailed description based on petrographic observations and X-rays diffraction investigations of several cores collected in the wells spudded in an oilfield belonging to Western Getic Basin. It was conducted a detailed characterization of the samples studied in terms of petrographic types, composition and microtexture, because as it is well known that such details cannot be provided by geophysical investigations.

Getic Basin is a major geological unit in Romania with a complex tectonic evolution, evolving as foredeep of the Southern Carpathians during Cretaceous to Paleogene period. Getic Basin could be divided in two sub-basins: Eastern Getic Basin with characters similar to the Eastern Carpathians Foredeep, and Western Getic Basin corresponding to a Paleogene to Early Miocene strike-slip basin developed on the contact zone between the Southern Carpathians and Moesian Platform. The complicated tectonic evolution of the Getic Basin varying from extension phase (Paleogene - Early Miocene) to compression phase (Middle Miocene - Early Sarmatian) was finalized by thrusting over Moesia during the Middle Miocene. [1-3]

Generally, Getic Basin is characterized by two basic structural systems: (1) internal folded foredeep, and (2) external epiplatform (unfolded) foredeep. In the Getic Basin the oil exploration began more than 100 years ago and resulted in thousands of wells drilled and tens of oils and gas fields discovered. Two petroleum systems are acting and evolving simultaneous in the Getic Basin: Oligocene-lower Miocene system and Sarmatian-Pliocene system. The petroleum systems consists of Oligocene marine source rocks that produce oil and gas accumulated in Oligocene to Pontian reservoirs in structural or combined traps. Trap formation is Middle Miocene with a minor reactivation during the Late Pliocene event. Most of the reservoirs in the Getic Basin are in the syn-compressional sediments and most-likely affected by strike-slip deformations, controlled by the anticlines growth and the position in respect with the main antiforms. [1, 4-8]

In the past oil exploration focused on relatively shallow depths $(2-4 \mathrm{~km})$, where large undiscovered traps are unlikely to exist to date. Thus, new play concepts were developed by OMV-Petrom (operator of main exploration and production blocks in the Getic Basin), which focus on deeper levels (4-6 km, i.e. the Paleogene of the Getic Basin and the Mesozoic of the under-thrusted Moesia), where potentially large gas accumulations are present and were confirmed by latest hydrocarbon discoveries such as Totea Deep and Mamu gas fields. [1, 6-8]

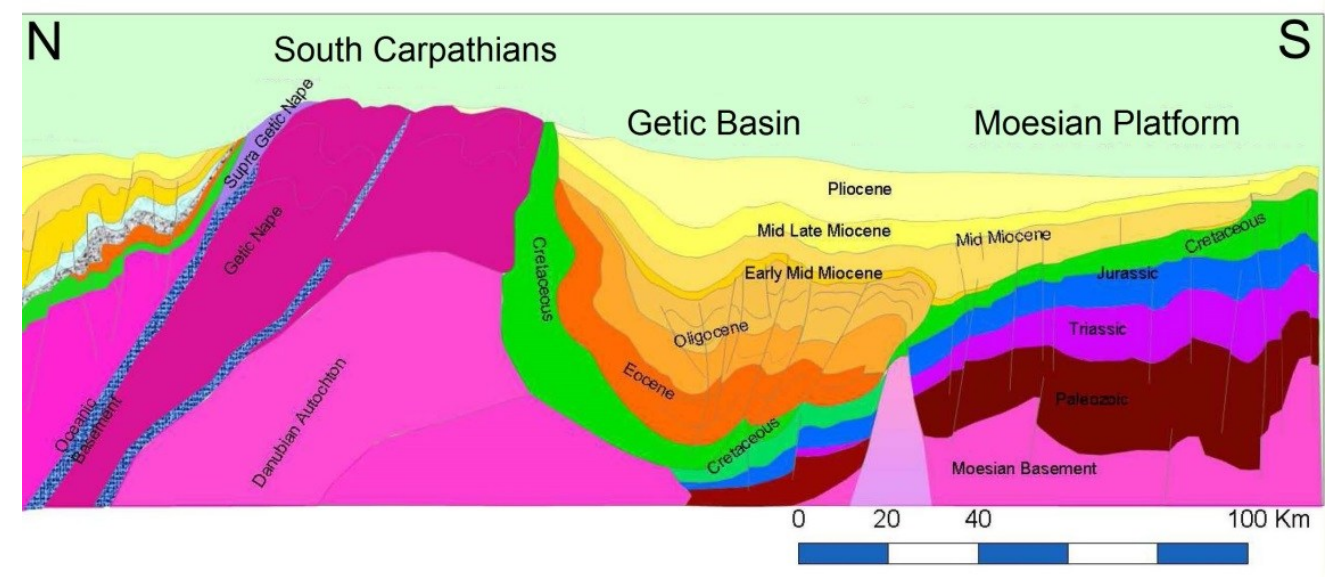

Fig. 1 Regional cross-section in the major geological units in South Romania [6] 
The oilfield studied is located in the Gorj County, $10 \mathrm{~km}$ south to the Targu Jiu city, and geologically belongs to the Western Getic Basin and to Calnic-Ciuperceni-Targu JiuColibasi-Alunu structural trend respectively. The oilfield structure is a faulted anticline affected by a tectonic system of longitudinal and transversal faults. The wells spudded in the structure were crossed deposits belonging to Oligocene, Burdigalian, Sarmatian, and Pliocene geological ages. [9-10]

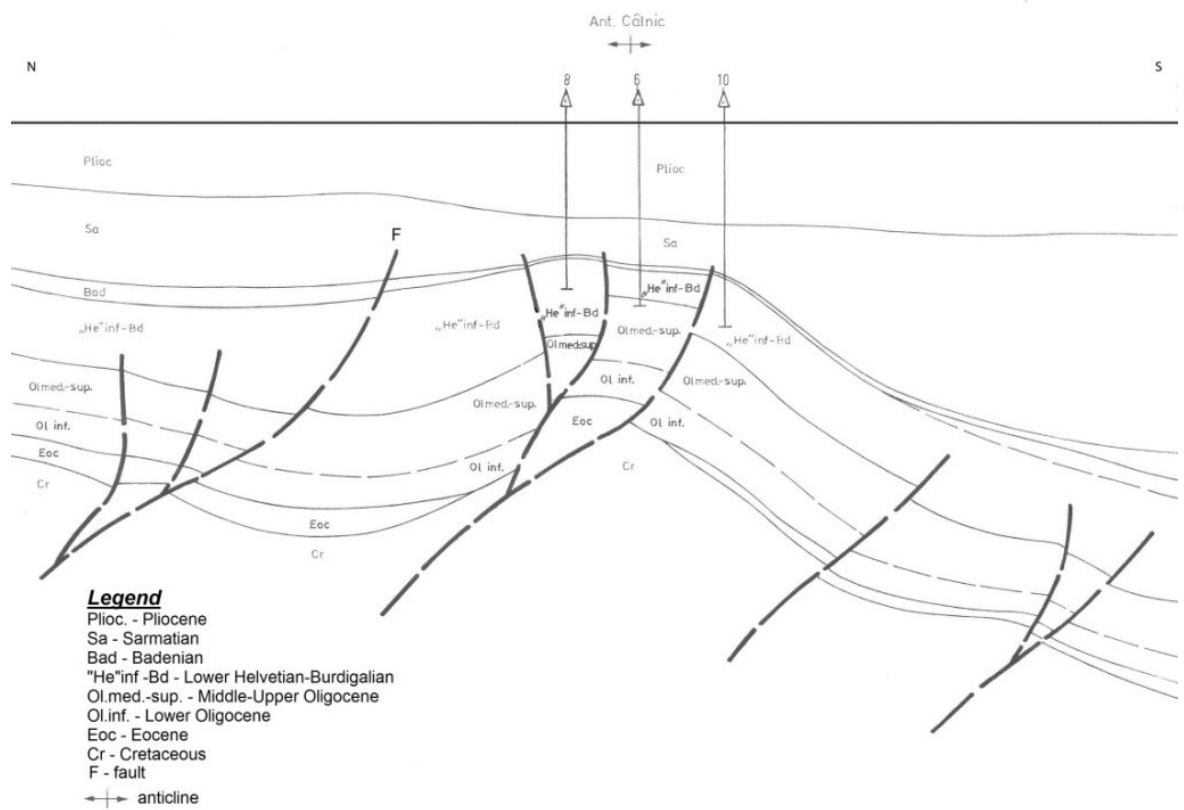

Fig. 2 Geologic cross-section showing the structural style in the studied area (no scale)

The exploration phase started in 1951-1957 period and since 1959 the exploration wells were evidenced in the production tests the existence of oil and gas accumulations in Oligocene and Miocene (Burdigalian and Sarmatian) deposits and confirmed the commercial oil discovery. In the oilfield studied were drilled over 50 wells of which 26 wells have positive results in production tests and 21 wells entering in production, and daily production (Burdigalian and Sarmatian reservoirs) is around 3,000 barrels per day. [9-10] The average values of main parameters of the oil-bearing formations in the oilfield studied are presented in the table 1 .

Table 1. Main physical parameters of the oil reservoirs in the oilfield studied [9]

\begin{tabular}{|l|l|l|l|}
\hline Reservoir physical parameters & Oligocene & Burdigalian & Sarmatian \\
\hline Porosity $(\%)$ & $14-19$ & $2.50-20.50$ & $14-20$ \\
\hline Permeability $(\mathrm{mD})$ & 35 & $0.50-1.10$ & $0.50-50$ \\
\hline Irreducible water saturation (\%) & $35-44$ & $13-38.50$ & 40 \\
\hline Oil volume factor & 1.53 & 1.272 & 1.272 \\
\hline Oil specific gravity $\left(\mathrm{Kg} / \mathrm{m}^{3}\right)$ & 0.835 & 0.835 & 0.835 \\
\hline Reservoir pressure $(\mathrm{bar})$ & 258 & 138 & $140-173$ \\
\hline Solution gas-oil ratio $\left(\mathrm{Sm}^{3} / \mathrm{m}^{3}\right)$ & 220 & 85 & 85 \\
\hline Temperature $\mathrm{T}\left({ }^{\circ} \mathrm{C}\right)$ & 76 & $55-63$ & 50 \\
\hline
\end{tabular}




\section{Experimental data}

In order to perform the petrographic study were manufactured thin sections from the rock samples belonging to Burdigalian (classical Helvetian) and Sarmatian. Thin sections were prepared to investigate the optical properties of the minerals in transmitted light and helping to reveal the rock types, origin and evolution of the parent rock. The petrographic study of the thin sections is essential to correct interpretation of rock types and their petrogenesis. The petrographic study was performed using a polarizing optical microscope Leica type. Pictures were taken with a capture incorporated camera.

The mineralogical composition of the rock samples analyzed was determined by X-rays diffraction (XRD) technique. In order to prepare the powders for the measurements the rock samples were grinded in an agate mortar. XRD data were obtained using a Bruker D8 Advance diffractometer under following measurement conditions: $\mathrm{CuK} \alpha$ radiation $(\lambda=1,54 \AA ; 40 \mathrm{kV} ; 40 \mathrm{~mA})$, Bragg-Brentano geometry, step $0.1^{\circ}$, scan speed $0.1^{\circ} / 5 \mathrm{~s}$, and measurement range $(2 \theta) 1-60^{\circ}$. In order to modeling of the emission source profile were used NIST SRM 660a and SRM 676 profile standards. XRD measurements were interpreted both qualitative and quantitative. Diffracplus Basic software and PDF-ICDD 22008 database were used for qualitative interpretation of XRD measurements, while TOPAS 4.1 software was used for quantitative interpretation of XRD measurements by Rietveld method (refinement). The figures of merit of the Rietveld refinements are represented by the Rwp (R-weighted pattern), GOF (goodness-of-fit) and DW (DurbinWatson d-statistic). [11-13]

\section{Results and discussions}

Petrographic study of the thin sections led to the conclusion that rock samples analyzed belong to the epiclastic sedimentary rocks (conglomerates, breccias, sands, sandstones, claystones and marlstones), and carbonate rocks (limestones).

Our goal was to provide a detailed characterization of these rock samples in terms of variety, composition and microstructures, information that cannot be obtained by indirect investigation methods such as geophysical and hydrodynamic investigations. The samples analyzed are composed of detrital fraction (represented by granoclasts, lithoclasts and bioclasts) and a fine-grained, clay-carbonate matrix.

The samples belonging to the Sarmatian are characterized by a fine-grained lithofacies (claystones, marlstones and fine sands) while the cores from Burdigalian are characterized by a coarser lithofacies (conglomerates, breccias, sandstones).

The samples of Burdigalian age (i.e. SWC 1 to SWC 20) were assigned to clast-arenites rocks like greywacke, clayey greywacke, clay sands, accidentally detrital limestones, in the base of the Burdigalian deposits, and to the top of Burdigalian sedimentary suite mainly clast-rudites rocks like conglomerates and microbreccias with metamorphic elements (microquartzite, greenschists, gneiss, mylonite, granitoids) and respectively limestones.

The four samples of Sarmatian age (i.e. SWC 21 to SWC 24) revealed a transition to fine-grained (clayey-marly) fraction: in the base marlstones and clayey sands, and to the top calcareous claystones. The microscopic investigations carried out on the sample rocks analyzed are summarized in the table 2. 
Table 2. Mineralogical and petrographic characteristics of the sample rocks analyzed

\begin{tabular}{|c|c|c|c|}
\hline $\begin{array}{l}\text { Sample } \\
\text { code }\end{array}$ & $\begin{array}{l}\text { Geological } \\
\text { age }\end{array}$ & Microscopic description & $\begin{array}{l}\text { Rock } \\
\text { diagnosis }\end{array}$ \\
\hline SWC1 & $\begin{array}{l}\text { Miocene } \\
\text { (Burdigalian) }\end{array}$ & $\begin{array}{l}\text { Epiclastic sedimentary rock, homogeneous from } \\
\text { petrographic point of view, composed mainly of } \\
\text { epiclasts (quartz, feldspars, micas, calcites) and } \\
\text { phyllosilicate-clayey cement (fig. 3). Epiclasts are } \\
\text { divided in granoclasts, polygranular clasts and } \\
\text { lithoclasts. The shapes are various from angular to } \\
\text { subrounded. Sorting is moderate. }\end{array}$ & Clayey sand \\
\hline SWC3 & $\begin{array}{l}\text { Miocene } \\
\text { (Burdigalian) }\end{array}$ & $\begin{array}{l}\text { Epiclastic sedimentary rock, weak consolidated, } \\
\text { grey-whitish, composed of detrital fraction } \\
\text { represented by lithoclasts (microquartzite with } \\
\text { granoblastic texture) and granoclasts (quartz, } \\
\text { plagioclase, microcline, micas, calcite) in a clayey- } \\
\text { phyllosilicate matrix (fig. 4) with filling and pellicle } \\
\text { character. }\end{array}$ & Greywacke \\
\hline SWC4 & $\begin{array}{l}\text { Miocene } \\
\text { (Burdigalian) }\end{array}$ & $\begin{array}{l}\text { Epiclastic sedimentary rock, weak consolidated, } \\
\text { grey-greenish, composed of angular fragments in } \\
\text { clayey-silt mass (fig. 5). The rock sample is } \\
\text { composed of detrital fraction of lithoclasts } \\
\text { (microquartzite and quartzite schist with grano- } \\
\text { lepidoblastic texture) and granoclasts (angular to } \\
\text { subrounded quartz, feldspars, micas, calcite) in a } \\
\text { phyllosilicate-clayey matrix with basal character. }\end{array}$ & $\begin{array}{l}\text { Clayey } \\
\text { sandstone }\end{array}$ \\
\hline SWC5 & $\begin{array}{l}\text { Miocene } \\
\text { (Burdigalian) }\end{array}$ & $\begin{array}{l}\text { Sedimentary rock, non-homogeneous from } \\
\text { petrographic point of view, composed of two } \\
\text { petrographic types: micrite limestone } \\
\text { (homogeneous type without allochems) and, } \\
\text { subordinate, epiclasts (quartz, plagioclase, } \\
\text { microcline, micas) and phyllosilicate cement } \\
\text { (fig. 6). The shapes of epiclasts are variable, from } \\
\text { rounded to subangular (prevailing the subrounded } \\
\text { ones). }\end{array}$ & $\begin{array}{l}\text { Limestone } \\
\text { with } \\
\text { siliciclasts }\end{array}$ \\
\hline SWC6 & $\begin{array}{l}\text { Miocene } \\
\text { (Burdigalian) }\end{array}$ & $\begin{array}{l}\text { Epiclastic sedimentary rock, weak consolidated, } \\
\text { white-greyish, in which there are silt and arenite- } \\
\text { sized fractions. The rock sample (fig. 7) is } \\
\text { composed of detrital fraction represented by } \\
\text { lithoclasts (microquartzite) and granoclasts } \\
\text { (subangular quartz with undulose extinction; } \\
\text { twinned plagioclase; microcline, micas) and } \\
\text { subordinate phyllosilicate-clayey matrix, locally } \\
\text { clayey-carbonate, with pellicle character. The rock } \\
\text { shows very lower sorting grade, angularity of the } \\
\text { components and generally the matrix in small } \\
\text { quantities. }\end{array}$ & Greywacke \\
\hline SWC7 & $\begin{array}{l}\text { Miocene } \\
\text { (Burdigalian) }\end{array}$ & $\begin{array}{l}\text { Epiclastic sedimentary rock, homogeneous from } \\
\text { petrographic point of view (fig. 8), composed of } \\
\text { epiclasts (quartz, plagioclase, microcline, calcite) } \\
\text { and subordinate phyllosilicate (clayey) cement. } \\
\text { Epiclasts are predominant arenite-sized and } \\
\text { generally have rounded shapes. Sorting is moderate } \\
\text { to weak. Epiclasts can be divided in granoclasts, } \\
\text { polygranular clasts and lithoclasts. }\end{array}$ & Clayey sand \\
\hline
\end{tabular}




\begin{tabular}{|c|c|c|c|}
\hline SWC8 & $\begin{array}{l}\text { Miocene } \\
\text { (Burdigalian) }\end{array}$ & $\begin{array}{l}\text { Epiclastic sedimentary rock, medium consolidated, } \\
\text { grey-greenish, composed of lutite and arenite-sized } \\
\text { fractions. Arenite fragments have angular shape. } \\
\text { The rock is composed of detrital fraction of } \\
\text { lithoclasts (microquartzite and quartzite-micaceous } \\
\text { schist with grano-lepidoblastic texture) and } \\
\text { granoclasts (quartz, plagioclase, microcline) in a } \\
\text { silt-grained, clayey-phyllosilicate matrix with basal } \\
\text { character (fig. 9). }\end{array}$ & $\begin{array}{l}\text { Clayey } \\
\text { greywacke }\end{array}$ \\
\hline SWC9 & $\begin{array}{l}\text { Miocene } \\
\text { (Burdigalian) }\end{array}$ & $\begin{array}{l}\text { Epiclastic sedimentary rock, weak consolidated, } \\
\text { white-greyish, composed of rudite and arenite-sized } \\
\text { elements. It can be observed lamellas of micas. The } \\
\text { rock sample (fig. 10) is predominant composed of } \\
\text { detrital fraction (angular, broken fragments of } \\
\text { lithoclasts: microquartzite and quartz-feldspathic } \\
\text { rock with granoblastic texture; and granoclasts: } \\
\text { quartz, plagioclase, micas, calcite) and clay- } \\
\text { phyllosilicate matrix (subordinate) with filling and } \\
\text { pellicle character. }\end{array}$ & $\begin{array}{l}\text { Polymictic } \\
\text { conglomerate }\end{array}$ \\
\hline SWC10 & $\begin{array}{l}\text { Miocene } \\
\text { (Burdigalian) }\end{array}$ & $\begin{array}{l}\text { Epiclastic sedimentary rock, weak aggregate, white- } \\
\text { greyish, composed relatively uniform of arenite- } \\
\text { sized elements. The rock sample (fig. 11) is } \\
\text { predominant composed of detrital fraction } \\
\text { (lithoclasts: microquartzite with muscovite, rounded } \\
\text { elements; and granoclasts: quartz, twinned } \\
\text { plagioclase, microcline, micas) and a chemical } \\
\text { carbonate cement, locally clay-phyllosilicate matrix. } \\
\text { Calcite cement has filling and pellicle character }\end{array}$ & $\begin{array}{l}\text { Polymictic } \\
\text { conglomerate }\end{array}$ \\
\hline SWC11 & $\begin{array}{l}\text { Miocene } \\
\text { (Burdigalian) }\end{array}$ & $\begin{array}{l}\text { Sedimentary rock, heterogeneous from petrographic } \\
\text { point of view. There are two domains (fig. 12), both } \\
\text { composed of epiclasts (quartz, plagioclase, } \\
\text { microcline, chlorite, micas, epidote, apatite and } \\
\text { titanite) and micrite and sparite carbonate as cement } \\
\text { or clasts. Sparite carbonate (calcite) is predominant } \\
\text { in the sample over micrite carbonate. Some } \\
\text { epiclasts (siliciclasts) have rudite dimensions. } \\
\text { Sorting is weak. Rudite lithoclasts belongs to } \\
\text { metamorphic rocks (gneisses, greenschists). The } \\
\text { shapes of siliciclasts are subangular to subrounded. }\end{array}$ & $\begin{array}{l}\text { Carbonate } \\
\text { microbreccia }\end{array}$ \\
\hline SWC12 & $\begin{array}{l}\text { Miocene } \\
\text { (Burdigalian) }\end{array}$ & $\begin{array}{l}\text { Epiclastic sedimentary rock, weak aggregate, } \\
\text { relatively uniform, white-yellowish, composed of } \\
\text { rudite and arenite-sized elements (siliciclasts and } \\
\text { micro-sparite carbonate). The rock sample (fig. 13) } \\
\text { consist of predominant detrital fraction (angular } \\
\text { elements of lithoclasts: microquartzites, granoclasts: } \\
\text { quartz with undulose extinction, twinned } \\
\text { plagioclase, microcline, chlorite, micas, calcite) and } \\
\text { phyllosilicate-clay matrix with filling character }\end{array}$ & $\begin{array}{l}\text { Polymictic } \\
\text { conglomerate }\end{array}$ \\
\hline SWC13 & $\begin{array}{l}\text { Miocene } \\
\text { (Burdigalian) }\end{array}$ & $\begin{array}{l}\text { Epiclastic sedimentary rock, relative homogeneous } \\
\text { from petrographic point of view. The rock sample } \\
\text { (fig. 14) is composed of epiclasts and cement of } \\
\text { basal type. Basal cement is micritic carbonate and } \\
\text { subordinate, in some microareas is clayey } \\
\text { phyllosilicate. Sorting of the rock is moderate to } \\
\text { good. Epiclasts are represented by granoclasts }\end{array}$ & $\begin{array}{l}\text { Calcareous } \\
\text { sandstone }\end{array}$ \\
\hline
\end{tabular}




\begin{tabular}{|c|c|c|c|}
\hline & & $\begin{array}{l}\text { (quartz, plagioclase, microcline, micas, chlorite, } \\
\text { carbonate (as calcite microcrystals) and } \\
\text { polygranular clasts (quartz, carbonate, microcline, } \\
\text { plagioclase, and micas). }\end{array}$ & \\
\hline SWC14 & $\begin{array}{l}\text { Miocene } \\
\text { (Burdigalian) }\end{array}$ & $\begin{array}{l}\text { Epiclastic sedimentary rock, homogeneous from } \\
\text { petrographic point of view. The rock sample (fig. } \\
\text { 15) is composed of fragments of quartz-feldspathic } \\
\text { rocks (granitoids) and clay-carbonate matrix with } \\
\text { isotropic character. The fragments originating from } \\
\text { granitoids rocks have variable dimensions (rudite to } \\
\text { arenite), and mineralogical composition is: feldspars } \\
\text { (microcline, plagioclase), quartz, micas, chlorite, } \\
\text { apatite, garnet. The clay matrix originates from the } \\
\text { weathering of the feldspars, and rarely clasts of } \\
\text { micrite carbonate are disseminated in the matrix. }\end{array}$ & $\begin{array}{l}\text { Polymictic } \\
\text { conglomerate }\end{array}$ \\
\hline SWC15 & $\begin{array}{l}\text { Miocene } \\
\text { (Burdigalian) }\end{array}$ & $\begin{array}{l}\text { Epiclastic sedimentary rock, weak consolidated, } \\
\text { white-greyish, composed of rudite and arenite-sized } \\
\text { elements. The rock sample (fig. 16) is predominant } \\
\text { composed of detrital fraction (fragments of } \\
\text { lithoclasts: microquartzite and quartz-feldspathic } \\
\text { rock with granoblastic texture; and granoclasts: } \\
\text { quartz, plagioclase, micas, calcite) and a clay- } \\
\text { phyllosilicate matrix (subordinate) with filling and } \\
\text { pellicle character. }\end{array}$ & $\begin{array}{l}\text { Polymictic } \\
\text { conglomerate }\end{array}$ \\
\hline SWC16 & $\begin{array}{l}\text { Miocene } \\
\text { (Burdigalian) }\end{array}$ & $\begin{array}{l}\text { Sedimentary rock, weak aggregate, yellow-whitish, } \\
\text { composed of randomly oriented fragments/clasts. } \\
\text { The rock sample (fig. 17) is composed of angular, } \\
\text { broken clasts of metamorphic rock: mylonite, and } \\
\text { quantitative reduced, clay-phyllosilicate matrix with } \\
\text { pellicle character. It was observed microareas of } \\
\text { mother quartzite rock in a fundamental mylonite } \\
\text { mass. Along these microareas there are rare fine- } \\
\text { grained clasts of micrite limestone. }\end{array}$ & Breccia \\
\hline SWC17 & $\begin{array}{l}\text { Miocene } \\
\text { (Burdigalian) }\end{array}$ & $\begin{array}{l}\text { Epiclastic sedimentary rock, weak consolidated, } \\
\text { non-homogeneous from petrographic point of view. } \\
\text { The rock sample (fig. 18) includes epiclasts } \\
\text { (granoclasts: quartz, plagioclase, microcline, micas, } \\
\text { chlorite, garnet, zircon; and lithoclast: micrite } \\
\text { limestone, clastic limestones) representing approx. } \\
80-90 \% \text { of total volume, and clay-carbonate matrix. } \\
\text { Epiclasts have variable shapes, subangular and } \\
\text { subrounded. Arenite-sized epiclasts are } \\
\text { representative, but there are also silt-sized } \\
\text { granoclasts and rarely rudite epiclasts. The matrix is } \\
\text { composed of clayey phyllosilicates (illite and } \\
\text { clinochlore) and microcrystalline carbonate (mostly } \\
\text { clastic). Sorting is weak. }\end{array}$ & Clayey sand \\
\hline SWC18 & $\begin{array}{l}\text { Miocene } \\
\text { (Burdigalian) }\end{array}$ & $\begin{array}{l}\text { Epiclastic sedimentary rock composed of rudite and } \\
\text { arenite-sized epiclasts (fig. 19) and phyllosilicate } \\
\text { matrix (subordinate). Epiclasts are represented by } \\
\text { subangular to subrounded granoclasts (quartz, } \\
\text { microcline, plagioclase, micas, garnet), } \\
\text { polygranular clasts (quartz, plagioclase, sericite, } \\
\text { chlorite) and lithoclasts (claystones, limestones, } \\
\text { mylonites). Composition of the matrix is }\end{array}$ & $\begin{array}{l}\text { Polymictic } \\
\text { microconglom } \\
\text { erate }\end{array}$ \\
\hline
\end{tabular}




\begin{tabular}{|c|c|c|c|}
\hline & & $\begin{array}{l}\text { predominant clay-phyllosilicate (illite) and } \\
\text { subordinate include carbonate as fine crystals. The } \\
\text { presence of rudite granoclasts of quartz and } \\
\text { feldspars lead to the assumption that they originate } \\
\text { from either macroblastic gneisses or pegmatites }\end{array}$ & \\
\hline SWC19 & $\begin{array}{l}\text { Miocene } \\
\text { (Burdigalian) }\end{array}$ & $\begin{array}{l}\text { Epiclastic sedimentary rock, homogeneous } \\
\text { petrographic. The rock sample (fig. 20) is composed } \\
\text { of fragments of quartz-feldspathic rocks (probably } \\
\text { granitoids) and clay-carbonate matrix. The } \\
\text { fragments originating from quartz-feldspathic rocks } \\
\text { have rudite to arenite dimensions, and mineralogical } \\
\text { composition is: feldspars (microcline, plagioclase), } \\
\text { quartz, micas, chlorite, garnet. The clay matrix } \\
\text { originate from weathering of the feldspars. Fine- } \\
\text { grained clasts of micrite limestone are disseminated } \\
\text { in the clay matrix. }\end{array}$ & $\begin{array}{l}\text { Polymictic } \\
\text { conglomerate }\end{array}$ \\
\hline SWC20 & $\begin{array}{l}\text { Miocene } \\
\text { (Burdigalian) }\end{array}$ & $\begin{array}{l}\text { Epiclastic sedimentary rock, weakly aggregate, } \\
\text { grey-whitish, in which are distinguished rare } \\
\text { angular quartz elements. The rock sample (fig. 21) } \\
\text { is predominant composed of detrital fraction and } \\
\text { carbonate cement, locally carbonate-clay cement. } \\
\text { Detrital fraction is composed of lithoclasts (micrite } \\
\text { limestone; metamorphic rocks with grano- } \\
\text { lepidoblastic texture: quartz-muscovite schist, } \\
\text { microquartzite, quartz-feldspathic rock) and } \\
\text { granoclasts (angular quartz with undulose } \\
\text { extinction, twinned plagioclase). The calcite cement } \\
\text { has chemical type with filling and pellicle character. }\end{array}$ & $\begin{array}{l}\text { Polymictic } \\
\text { conglomerate }\end{array}$ \\
\hline SWC21 & $\begin{array}{l}\text { Miocene } \\
\text { (Sarmatian) }\end{array}$ & $\begin{array}{l}\text { Epiclastic sedimentary rock, relative homogeneous } \\
\text { from petrographic point of view. The rock sample } \\
\text { (fig. 22) is composed of clayey-carbonate matrix of } \\
\text { crypto-microcrystalline phyllosilicates (illite and } \\
\text { smectite) and micrite carbonates, and epiclasts (silt- } \\
\text { grained quartz, plagioclase feldspar and particles of } \\
\text { opaque minerals). The rock is composed of two } \\
\text { domains, both having clayey-carbonate dominant } \\
\text { composition. The clayey mass are composed mainly } \\
\text { of clayey phyllosilicate (one with predominant } \\
\text { foliated habit = illite and the other cryptocrystalline } \\
\text { - probably smectite) and subordinate other clayey } \\
\text { phyllosilicates (chlorite). Also in the matrix there } \\
\text { are present as major component, micrite carbonate } \\
\text { (calcite). Epiclasts are randomly distributed in the } \\
\text { matrix, can be locally concentrated in some } \\
\text { microareas. }\end{array}$ & Marlstone \\
\hline SWC22 & $\begin{array}{l}\text { Miocene } \\
\text { (Sarmatian) }\end{array}$ & $\begin{array}{l}\text { Epiclastic sedimentary rock, homogeneous from } \\
\text { petrographic point of view. The rock sample (fig. } \\
\text { 23) is composed of epiclasts (angular and } \\
\text { subrounded siliciclasts) and a clayey-phyllosilicate } \\
\text { matrix. Subordinate compared with siliciclasts can } \\
\text { be found carbonate clasts. Larger part of the volume } \\
\text { of epiclasts is represented by the arenite ones. } \\
\text { Sorting is weak. Epiclasts are represented by } \\
\text { granoclasts (quartz, plagioclase, microcline, micas, } \\
\text { monocrystalline calcite, chlorite, garnet, staurolite, } \\
\text { kyanite) and polygranular clasts (quartz, sericite, }\end{array}$ & Clayey sand \\
\hline
\end{tabular}




\begin{tabular}{|c|c|c|c|}
\hline & & $\begin{array}{l}\text { micrite and sparite carbonate, biotite, muscovite, } \\
\text { chlorite and opaque mineral). The matrix is } \\
\text { composed of clayey phyllosilicates (illite and } \\
\text { clinochlore). }\end{array}$ & \\
\hline SWC23 & $\begin{array}{l}\text { Miocene } \\
\text { (Sarmatian) }\end{array}$ & $\begin{array}{l}\text { Epiclastic sedimentary rock, homogeneous from } \\
\text { petrographic point of view. The rock sample (fig. } \\
\text { 24) is composed mainly of clayey phyllosilicates } \\
\text { and subordinate other minor constituents (epiclasts } \\
\text { and carbonate). Clayey phyllosilicates are } \\
\text { cryptocrystalline phyllosilicate = smectite } \\
\text { (predominant in the sample), microcrystalline } \\
\text { phyllosilicate with foliated habit - most likely illite, } \\
\text { and also clayey chlorite. Microcrystalline } \\
\text { phyllosilicate is unevenly distributed in the rock } \\
\text { mass. Minor constituents are represented by } \\
\text { epiclasts (granoclasts of quartz, plagioclase, micas) } \\
\text { and microcrystalline calcite as crystals or } \\
\text { microclasts unevenly distributed in rock mass. }\end{array}$ & $\begin{array}{l}\text { Calcareous } \\
\text { claystone }\end{array}$ \\
\hline SWC24 & $\begin{array}{l}\text { Miocene } \\
\text { (Sarmatian) }\end{array}$ & $\begin{array}{l}\text { Epiclastic sedimentary rock, weak heterogeneous in } \\
\text { microscopic scale from petrographic point of view. } \\
\text { The rock sample (fig. 25) is composed of two } \\
\text { domains, both having clay-carbonate dominant } \\
\text { composition. Difference between the two domains } \\
\text { consists of the content of silt-sized siliciclasts and } \\
\text { subordinate arenite (especially granoclasts of } \\
\text { quartz, plagioclase, chlorite, micas) and the } \\
\text { carbonate content. The clay-carbonate mass is } \\
\text { composed mainly of clayey phyllosilicates and } \\
\text { micrite carbonate. Clay phyllosilicates are } \\
\text { cryptocrystalline phyllosilicate = smectite } \\
\text { (predominant in the sample), microcrystalline } \\
\text { phyllosilicate with foliated habit-most likely illite, } \\
\text { and also clayey chlorite. The second component as } \\
\text { proportion of volume is microcrystalline carbonate } \\
\text { (calcite) as microcrystals dispersed in clayey mass } \\
\text { and microaggregates. }\end{array}$ & $\begin{array}{l}\text { Calcareous } \\
\text { claystone }\end{array}$ \\
\hline
\end{tabular}

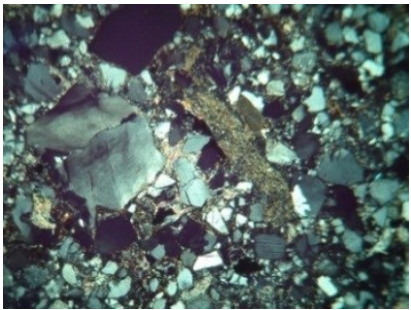

Fig. 3 Granoclasts of quartz, plagioclase, microcline, lithoclasts of micrite carbonate in clay-phyllosilicate cement $(\mathrm{N}+, 40 \mathrm{x})$

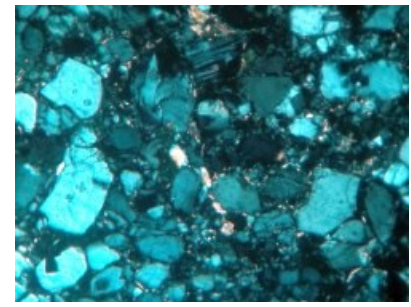

Fig. 4 Granoclasts of quartz, plagioclase, microcline and micas in clay-phyllosilicate matrix $(\mathrm{N}+, 100 \mathrm{x})$

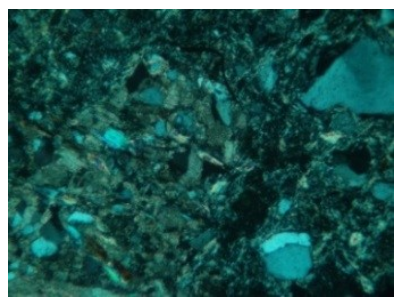

Fig. 5 Granoclasts of quartz, angular to subrounded, in clay-phyllosilicate matrix $(\mathrm{N}+, 100 \mathrm{x})$ 


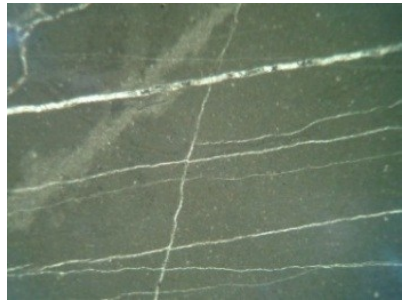

Fig. 6 Overall structure of the micrite limestone with a system of quasi-parallel diaclases $(\mathrm{N}+, 40 \mathrm{x})$

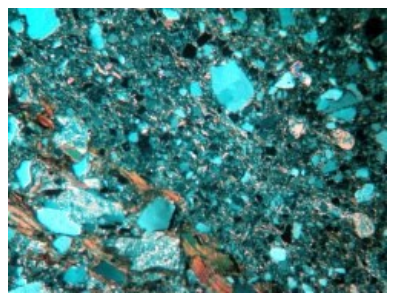

Fig. 9 Granoclasts of quartz and micas and lithoclasts of microquartzite in clayphyllosilicate matrix $(\mathrm{N}+$, 40x)

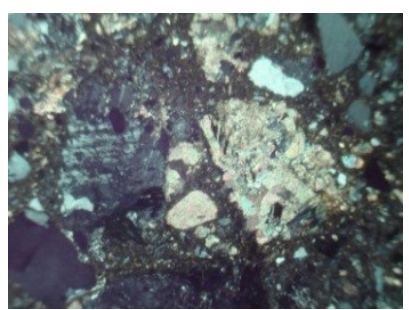

Fig. 12 Polygranular clast of plagioclase, chlorite, quartz and apatite; polygranular clast of carbonate; in micrite carbonate matrix $(\mathrm{N}+, 60 \mathrm{x})$

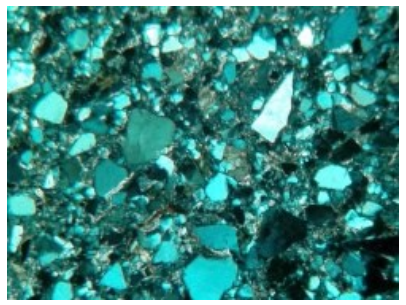

Fig. 7 Granoclasts of subangular quartz with undulose extinction and twinned plagioclase $(\mathrm{N}+, 40 \mathrm{x})$

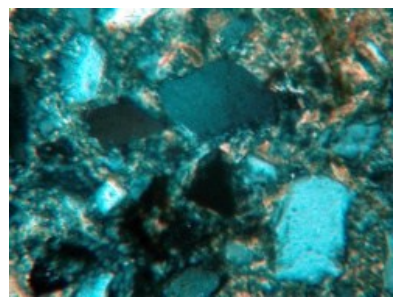

Fig. 10 Granoclasts of quartz and micas in clay-phyllosilicate matrix $(\mathrm{N}+, 250 \mathrm{x})$

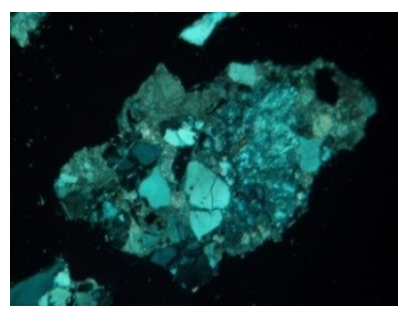

Fig. 13 Granoclasts of quartz with undulose extinction in the phyllosilicate-clay matrix $(\mathrm{N}+$, 40x)

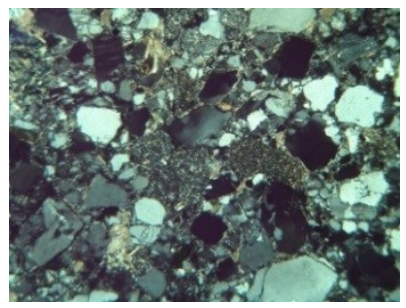

Fig. 8 Granoclasts and polygranular clasts of quartz, plagioclase, microcline, chlorite, in clay-phyllosilicate cement $(\mathrm{N}+, 40 \mathrm{x})$

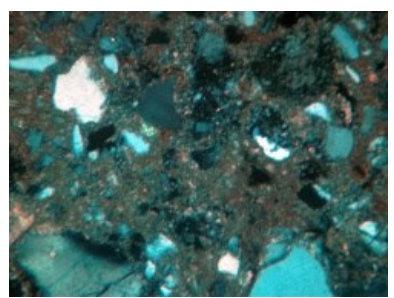

Fig. 11 Granoclasts of quartz in chemical cement of calcite with filling character. Locally, clay-phyllosilicate matrix $(\mathrm{N}+, 100 \mathrm{x})$

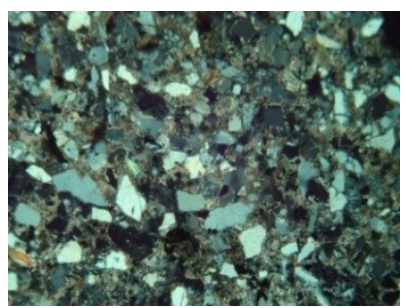

Fig. 14 Granoclasts of quartz, plagioclase, muscovite, microcline, and opaque organic substance in basal-type carbonate cement $(\mathrm{N}+, 40 \mathrm{x})$ 


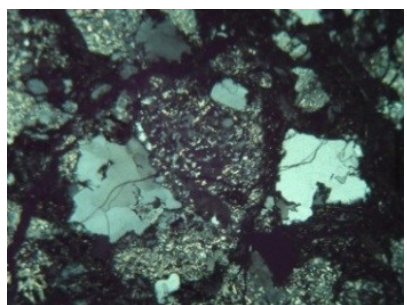

Fig. 15 Fragments of quartzfeldspathic rock (sericitized feldspar, quartz, and plagioclase) in clay-carbonate matrix $(\mathrm{N}+, 40 \mathrm{x})$

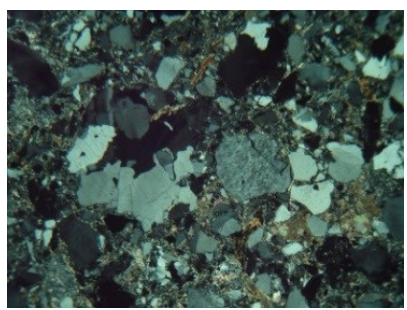

Fig. 18 Polygranular clasts and granoclasts of quartz, microcline, plagioclase, chlorite, micas) of various dimensions in phyllosilicatecarbonate matrix $(\mathrm{N}+, 40 \mathrm{x})$

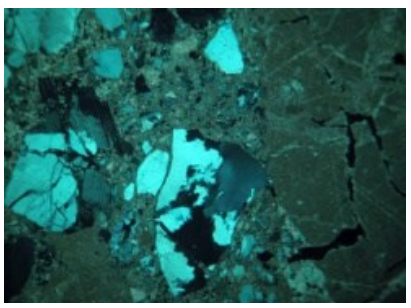

Fig. 21 Lithoclasts of micrite limestone and microquartzite in the carbonate cement $(\mathrm{N}+$, 40x)

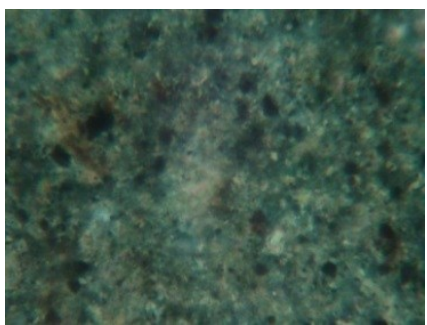

Fig. 24 Anhedral particles of carbonate in clayey mass predominant cryptocrystalline $(\mathrm{N}+, 600 \mathrm{x})$

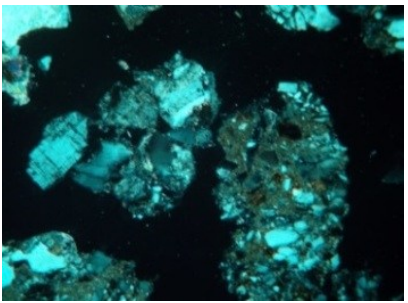

Fig. 16 Lithoclast of microquartzite and granoclasts of quartz in clay-phyllosilicate matrix $(\mathrm{N}+, 40 \mathrm{x})$

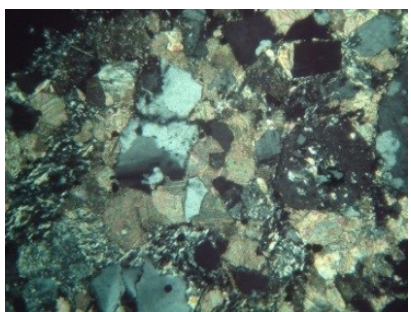

Fig. 19 Polygranular clast of quartz and granoclasts of plagioclase in various stages of sericitization in sparitic carbonate cement $(\mathrm{N}+, 100 \mathrm{x})$

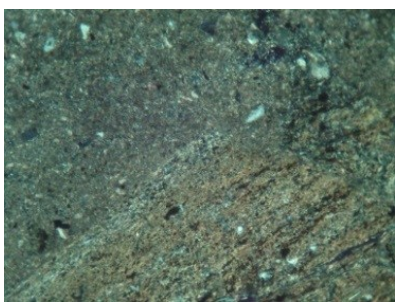

Fig. 22 Clay-carbonate matrix (clay minerals and micrite carbonate) and epiclasts of quartz and plagioclase $(\mathrm{N}+, 100 \mathrm{x})$

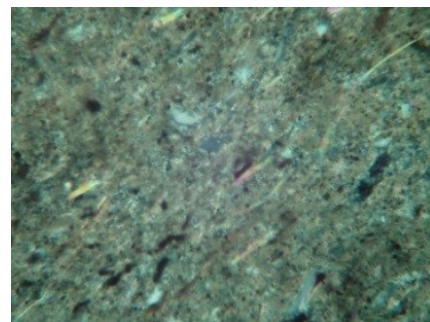

Fig. 25 Granoclasts of quartz and micas and carbonate particles in clayey mass predominant cryptocrystalline $(\mathrm{N}+, 250 \mathrm{x})$

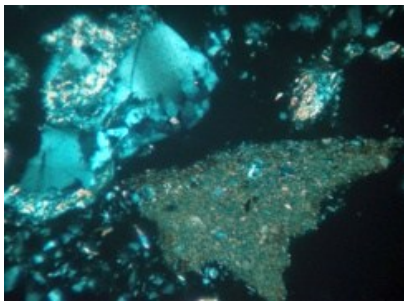

Fig. 17 Angular fragments of quartzite rock and micritic limestone $(\mathrm{N}+, 100 \mathrm{x})$

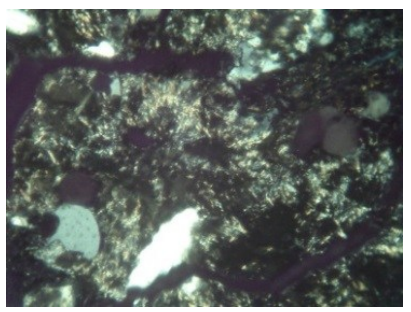

Fig. 20 Quartz-feldspathic fragments in microcryptocrystalline clay minerals and sericite $(\mathrm{N}+$, $100 \mathrm{x})$

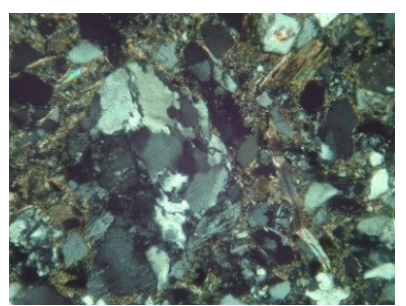

Fig. 23 Polygranular clasts and granoclasts composed of quartz, plagioclase, micas, chlorite in clay-carbonate matrix $(\mathrm{N}+, 100 \mathrm{x})$ 
XRD investigations were performed both qualitative and quantitative. In the XRD qualitative interpretation, the identification of the minerals using PDF-ICDD 2-2008 database was performed searching best quality marks: (*=high quality) and (I=indexed), after removing the background and $\mathrm{K} \alpha 2$ radiation. XRD quantitative interpretation of the samples analyzed was performed by Rietveld method. Quality of the Rietveld refinement is indicated by R-values (GOF and DW). XRD investigations show significant percentages for carbonate minerals (calcite), clay minerals (smectite, illite and clinochlore) and siliciclasts (quartz, plagioclase, microcline, micas). The mineralogical composition of rock samples analyzed resulted in the XRD quantitative analysis (wt\% Rietveld) is presented in table 3 .

Table 3. Mineralogical composition of the samples analyzed (XRD quantitative $-w t \%$ Rietveld)

\begin{tabular}{|c|c|c|c|c|c|c|c|c|}
\hline $\begin{array}{c}\text { Sample } \\
\text { code }\end{array}$ & Quartz & Plagioclase & Microcline & Micas & Calcite & $\begin{array}{r}\text { Smectit } \\
\mathbf{e}\end{array}$ & Illite & $\begin{array}{r}\text { Clinochlor } \\
\mathbf{e}\end{array}$ \\
\hline SWC 1 & 75.60 & 8.66 & 1.37 & 1.03 & 1.32 & - & 9.38 & 2.64 \\
\hline SWC 3 & 65.71 & 7.28 & 5.05 & 1.31 & 3.36 & - & 14.01 & 3.29 \\
\hline SWC 4 & 45.56 & 3.51 & 1.13 & 1.07 & 5.34 & 26.32 & 9.36 & 7.70 \\
\hline SWC 5 & 9.03 & 5.04 & - & 1.14 & 82.69 & - & - & 2.10 \\
\hline SWC 6 & 64.46 & 9.72 & 4.69 & 1.15 & 4.08 & - & 10.85 & 5.05 \\
\hline SWC 7 & 54.62 & 14.35 & 16.36 & 1.39 & 1.35 & - & 8.63 & 3.29 \\
\hline SWC 8 & 41.45 & 21.92 & 6.12 & 1.02 & & 3.77 & 12.69 & 13.02 \\
\hline SWC 9 & 64.41 & 17.45 & - & 2.03 & 1.18 & - & 7.30 & 7.63 \\
\hline SWC 10 & 48.16 & 9.66 & 4.75 & 2.66 & 26.07 & - & 6.69 & 2.02 \\
\hline SWC 11 & 9.39 & 16.21 & 2.83 & 1.01 & 62.33 & - & 1.30 & 6.93 \\
\hline SWC 12 & 61.73 & 6.20 & 2.72 & 2.78 & 18.76 & - & 4.20 & 3.61 \\
\hline SWC 13 & 47.35 & 12.84 & 4.28 & 1.45 & 25.05 & - & 5.78 & 3.25 \\
\hline SWC 14 & 29.89 & 11.73 & 42.76 & 3.10 & 4.19 & - & 3.01 & 5.31 \\
\hline SWC 15 & 62.95 & 4.32 & 7.58 & 2.20 & 4.18 & - & 10.91 & 7.86 \\
\hline SWC 16 & 67.13 & 5.61 & 1.60 & 3.06 & 1.93 & - & 9.21 & 11.46 \\
\hline SWC 17 & 51.07 & 16.45 & 2.60 & 1.16 & 14.41 & - & 7.85 & 6.46 \\
\hline SWC 18 & 53.75 & 7.85 & 2.92 & 2.68 & 23.57 & - & 6.64 & 2.58 \\
\hline SWC 19 & 24.26 & 22.78 & 37.61 & 2.19 & 5.15 & - & 3.72 & 4.29 \\
\hline SWC 20 & 41.88 & 13.22 & 4.14 & 2.03 & 26.11 & - & 2.01 & 10.61 \\
\hline SWC 21 & 3.74 & 2.03 & - & 1.13 & 29.22 & 40.52 & 17.75 & 5.62 \\
\hline SWC 22 & 65.50 & 19.72 & - & 1.11 & 1.79 & - & 9.36 & 2.51 \\
\hline SWC 23 & 7.42 & 2.57 & - & 1.03 & 14.28 & 65.48 & 7.33 & 1.88 \\
\hline SWC 24 & 6.24 & 1.03 & - & 1.04 & 23.02 & 45.23 & 18.76 & 4.68 \\
\hline
\end{tabular}

XRD quantitative interpretation of the samples analyzed has GOF indices between 1.15 and 1.38 respectively; most of values in the range 1.19-1.26; indicating their good quality. Also, the DW values between 1.89 and 2.30 respectively, most of DW values in the range 1.97-2.08, indicate the good quality of the XRD quantitative analysis [11-13].

\section{Conclusions}

Getic Basin is a major geological unit with a complex tectonic evolution in the Romanian Carpathian Orogen. In the Getic Basin during Tertiary period were acting and evolving simultaneous two petroleum systems. The cores analyzed in the paper were collected in wells spudded in an oil field located in the South-West Romania, and geologically belonging to Western Getic Basin and locally to Calnic-Ciuperceni-Targu Jiu-ColibasiAlunu structural trend.

In the paper we focused on detailed characterization of the rock samples studied in terms of petrographic types, composition and microtextures, information that cannot be 
obtained by indirect investigation methods such as geophysical and hydrodynamic investigations.

Petrographic study led to the conclusion that rock samples analyzed belongs to the epiclastic sedimentary rocks represented by conglomerates, breccias, sands, sandstones, claystones and marlstones, and carbonate rocks (limestones). The samples analyzed are composed of detrital fraction (represented by granoclasts, lithoclasts and bioclasts) and a fine-grained, clay-carbonate matrix. The samples belonging to the Sarmatian are characterized by a fine-grained lithofacies (claystones, marlstones and fine sands) while the samples from Burdigalian are characterized by a coarser lithofacies (conglomerates, breccias, sandstones). The samples of Burdigalian age (i.e. SWC 1 to SWC 20) were assigned to clast-arenites rocks like greywacke, clayey greywacke, clay sands, accidentally detrital limestones, in the base of the Burdigalian deposits, and to the top of Burdigalian sedimentary suite mainly clast-rudites rocks like conglomerates and microbreccias with metamorphic elements (microquartzite, greenschists, gneiss, mylonite, granitoids) and respectively limestones. The four samples of Sarmatian age (i.e. SWC 21 to SWC 24) revealed a transition to fine-grained (clayey-marly) fraction: in the base marlstones and clayey sands, and to the top calcareous claystones.

XRD investigations indicated the phyllosilicates (smectite and illite) as main minerals in the Sarmatian samples, while in the Burdigalian samples were found as main minerals: quartz, feldspars and carbonate minerals. The paper provides detailed information (like petrographic types, composition and microtexture) on the Miocene reservoir rocks belonging to the Getic Basin, and the information obtained may be used in future reservoir modeling studies in the region.

\section{References}

1. C. Krezsek et al., 73rd EAGE Conference incorporating SPE EUROPEC 2011, New insights into the hydrocarbon system of the Getic Depression, Romania: implications for exploration, Vienna (2011)

2. T. Rabagia, L. Mațenco, Marine and Petroleum Geology, 16, 719 (1999)

3. S.M. Schmid, et al., Swiss J. Geosci., 101, 139 (2008)

4. B.M. Popescu, Petroleum Geoscience, 1 (4), 337 (1995)

5. M. Tilita, D. Tambrea, A. Boscaneanu, 73rd EAGE Conference incorporating SPE EUROPEC 2011, Western Getic Depression, Romania: New Architecture and Hydrocarbon Potential, Vienna (2011)

6. E.R. Stoica-Negulescu, AAPG Search and Discovery Article \#10928, 1 (2017)

7. G. Branoiu, General framework of exploration-production activities in Romania, (Editura Universitatii Petrol-Gaze din Ploiesti, 2019)

8. G. Branoiu et al., GEOLINKS, Is there a future for oil and gas exploration in Romania?, 1st edition, Athens, Greece, 1, 183 (2019)

9. D. Paraschiv, Romanian Oil and Gas Fields, Institutul de Geologie si Geofizica, Studii Tehnice si Economice, Serie A, Prospectiuni si Explorari Geologice, Bucharest, 13, 110 (1979)

10. C. Beca, D. Prodan, Geologia zăcămintelor de hidrocarburi (Editura Didactică şi Pedagogică, Bucureşti, 1983)

11. Bruker AXS GmbH, TOPAS 4 Tutorial (Karlsruhe, Germany, 2008)

12. R.A. Young, The Rietveld Method (IUCr Monographs on Crystallography, Oxford University Press, 1996)

13. V.K. Pecharsky, P.Y. Zavalij, Fundamentals of Powder Diffraction and Structural Characterization of Materials ( ${ }^{\text {nd }}$ Edition, Springer), Boston (2009) 